\title{
THE OCCURRENCE OF BACTERIOSTATIC PROPERTIES IN THE BLOOD OF PATIENTS AFTER RECOVERY FROM STREPTOCOCCAL PHARYNGITIS ${ }^{1}$
}

\author{
BY ANN G. KUTTNER AND T. F. LENERT \\ (From Irvington House, Irvington-on-Hudson, N. Y.)
}

(Received for publication June 7, 1943)

Although no definite proof is available, our observations covering 6 years suggest that repeated attacks of streptococcal pharyngitis occurring in the same individual are usually due to Group A streptococci of different types. Reinfection with the same type was never observed, suggesting that type-specific immunity may develop. At the present time, however, serological evidence of such immunity is meager.

\section{REVIEW OF LITERATURE}

Fothergill and Lium studied the bactericidal activity of the blood of 4 convalescent scarlet fever patients (1). Two of these patients recovered without developing complications; the other 2 developed otitis media, in one instance accompanied by mastoiditis, and in the other by adenitis. Only the 2 patients with purulent sequelae showed an increase in the bactericidal activity of the blood for the homologous streptococcus.

Hare reported the development of specific bactericidal properties in the blood of patients during the course of puerperal sepsis (2).

Spink and Keefer studied the streptococcidal power of defibrinated blood obtained from 30 erysipelas patients (3). An increase in bactericidal power for the homologous organism during the course of the disease was observed in one-third of the cases.

Chandler and Taussig, in a recent article, reported that the blood of 2 rheumatic children, who were carriers of Group A streptococci, were bactericidal for the homologous strains (4). The blood of 2 carriers of Group C streptococci was also found to contain homologous bactericidal antibodies.

Tillett (5) showed that sera obtained from patients acutely ill with a variety of infectious

\footnotetext{
1 This study was aided by a grant from The Dazian Foundation.
}

diseases, such as pneumonia, meningococcus meningitis, tuberculous pleurisy, as well as diseases due to streptococci, was highly bactericidal for certain strains of streptococci. This property disappeared as the patients recovered and was not considered to represent a specific immune response.

Swift and Hodge described the occurrence of type-specific anti-M precipitins in the sera of patients following streptococcal infections (6). Positive reactions were obtained, both in patients who developed rheumatic sequelae and in those who did not.

Walker (7) has reported the presence of typespecific agglutinins for the homologous streptococcus, demonstrable by the slide agglutination technique of Griffith, in the sera of 6 of 22 patients. The 6 positive reactions were obtained with sera of individuals recovering from purulent streptococcal infections (otitis media, empyema, and paronychia accompanied by axillary adenitis).

Rantz et al. reported the development of agglutinins for the homologous types, demonstrable by the slide agglutination technique, in 13 of 22 cases of scarlet fever (8).

Diefendorf (9) was able to demonstrate mouse protective antibodies in the sera of 10 of $14 \mathrm{pa}-$ tients. Six of these 10 sera were obtained from patients recovering from scarlet fever and 4 from rheumatic subjects during the fourth week of the rheumatic attack.

\section{MATERIAL}

Outbreak of streptococcal pharyngitis. As previously reported, an outbreak of pharyngitis, due to a Group A streptococcus of a single type, type 36 , occurred in this institution during the winter of 1941-1942 $(10,11)$. Six cases occurred in October, 9 in November, followed by 2 in December and one in January (making a total of 18 cases). Sera for the determination of antistreptolysin 0 titer, slide agglutination, and anti-M precipitin reactions were collected at frequent intervals, following the upper 
respiratory infection, from 16 of these 18 patients. Bacteriostatic tests with whole blood were not started until March 1942 when the outbreak had subsided and all the children were afebrile.

\section{EXPERIMENTAL}

Slide agglutination reactions. The sera of 10 children were tested by the slide agglutination method (Griffith) with the homologous as well as with heterologous types of Group A streptococcus (12). Five to 15 sera from each individual, obtained at intervals ranging from 1 day to 5 months after infection, were used. Slight agglutination occurred with a few sera from 7 children when tested with a strain of the homologous type. In every instance, however, equally strong or stronger reactions were observed with heterologous types. The results obtained by the slide agglutination test were therefore considered to be non-specific.

Anti-M precipitin reactions. The sera of 14 of these 18 children were tested for type specific anti-M precipitins (Lancefield (13)) for the homologous type 36 streptococcus. In 8 instances, 2 or more sera from the same child were used. The $M$ extract was used undiluted and diluted $1: 2$, $1: 4$, and $1: 8$. The results were uniformly negative. ${ }^{2}$

Protection tests. Protection tests were not performed because type 36 streptococcus was only slightly virulent for mice.

Bacteriostatic tests. In each test, the bacteriostatic activity of blood of children who had recovered from pharyngitis due to type 36 streptococcus was compared with that of children living in the institution who had escaped this streptococcal upper respiratory infection, and who were considered to be controls. Different children served as controls in experiments done at different times.

\section{BACTERIOSTATIC METHOD}

A modification of the technique described by Todd (15) was used. Most of the tests were done with the epidemicinducing strain, type 36 streptococcus, but in some experiments, recently isolated cultures of other types were included. All the cultures were preserved by drying on small pieces of filter paper in vacuo, according to the technique described by Brown (16). Numerous cultures of each strain were prepared. On the day before the test, one of these cultures was opened and the filter paper transferred to broth which was incubated for 18 to 20 hours. On the morning of the experiment, dilutions of the cultures were made in broth.

The blood was collected the morning of the test; 3 cc. of blood were placed in test tubes containing $1 \mathrm{mgm}$. of

In an outbreak of pharyngitis due to type 32 streptococcus (14), a few sera obtained after the subsidence of the upper respiratory infection were tested for type specific anti-M precipitins. It was found that sera which gave positive precipitin reactions with homologous $M$ extracts also reacted with $M$ extracts prepared from heterologous types. heparin (Hynson, Westcott, and Dunning). Nine-tenths cc. of heparinized blood was pipetted into test tubes of soft glass $(12 \mathrm{~cm}$. in length with an outside diameter of $7 \mathrm{~mm}$.). One-tenth cc. of a $10^{-5}$ or $10^{-6}$ dilution of culture was added. In some instances, $0.1 \mathrm{cc}$. of a $1: 2,000,000$ dilution was used. The number of bacteria inoculated varied considerably in different experiments. The best results were obtained when from 10 to 30 microorganisms were added to $0.9 \mathrm{cc}$. of blood. One-tenth $\mathrm{cc}$. of the infected blood was transferred immediately to $15 \mathrm{cc}$. of melted agar containing $0.5 \mathrm{cc}$. of horse blood and a "pour" plate made. The test tube containing the blood was then sealed by heat, placed in a shaking machine, and shaken for 3 hours, at moderate speed, while incubating at $37^{\circ} \mathrm{C}$. At the end of this period, $0.1 \mathrm{cc}$. was again transferred to $15 \mathrm{cc}$. of melted agar containing $0.5 \mathrm{cc}$. horse blood and a second "pour" plate made.

The number of colonies in the plates poured before and after incubation were counted. The horse blood was added to facilitate the counting of the colonies and exerted no demonstrable bacteriostatic effect.

The results of these bacteriostatic tests with the whole blood of 16 patients, $31 / 2$ to 17 months following pharyngitis due to type 36 streptococcus, are shown in Table $I$.

The tests recorded in Table I show a well marked difference between the bacteriostatic activity of the blood of children who had recovered from pharyngitis due to type 36 streptococcus, and that of children who had escaped this infection and who served as controls.

Children in whom the clinical symptoms due to this upper respiratory infection were mild or lacking, as well as those in whom they were moderately severe, developed this property. It was not correlated with the rise in antistreptolysin $O$ titer or the development of rheumatic sequelae. The bacteriostatic activity persisted for many months and in some instances could be demonstrated more than a year after the upper respiratory infection. In 3 patients, however, Cases 5, 6, and 14, who were tested after intervals of 16 to 17 months, a decrease in the bacteriostatic action of the blood was apparent.

Although the uniformity of the results obtained suggested that the bacteriostatic activity of these patients was definitely related to the type 36 streptococcal pharyngitis, it was thought of interest to determine whether this property was absent before infection. In 6 instances, the bacteriostatic activity of sera obtained before and after the upper respiratory infection was compared. Heparinized blood obtained from 
TABLE I

Bacteriostatic tests comparing the whole blood of children after recovery from streptococcus type 36 pharyngitis with those who escaped infection

\begin{tabular}{|c|c|c|c|c|c|c|c|c|c|c|}
\hline \multirow{3}{*}{$\begin{array}{l}\text { Case } \\
\text { No. }\end{array}$} & \multirow{3}{*}{$\begin{array}{l}\text { Name } \\
\text { Hosp. } \\
\text { No. }\end{array}$} & \multirow{3}{*}{ Age } & \multirow{2}{*}{\multicolumn{2}{|c|}{ Pharyngitis }} & \multirow{3}{*}{$\begin{array}{l}\text { Rise in anti- } \\
\text { streptolysin } \\
\text { O titer }\end{array}$} & \multirow{3}{*}{$\begin{array}{l}\text { Interval } \\
\text { between } \\
\text { infection } \\
\text { and } \\
\text { tests }\end{array}$} & \multirow{3}{*}{ Dates of tests } & \multicolumn{3}{|c|}{ Results } \\
\hline & & & & & & & & \multirow{2}{*}{$\begin{array}{l}\text { Patient } \\
\text { after } \\
\text { recovery }\end{array}$} & \multicolumn{2}{|c|}{$\begin{array}{l}\text { Children who } \\
\text { escaped type } \\
36 \text { pharyngitis }\end{array}$} \\
\hline & & & Date & Severity & & & & & $\begin{array}{c}\text { Control } \\
\text { No. } 1\end{array}$ & $\begin{array}{c}\text { Control } \\
\text { No. } 2\end{array}$ \\
\hline
\end{tabular}

9 PATIENTS WHO DEVELOPED RHEUMATIC MANIFESTATIONS

\begin{tabular}{|c|c|c|c|c|c|c|c|c|c|c|}
\hline 1 & J. W. & $\begin{array}{c}\text { years } \\
15\end{array}$ & October 27, 1941 & + & $\begin{array}{c}\text { wnits } \\
250 \text { to } 1000\end{array}$ & $\begin{array}{c}\text { months } \\
5 \\
5 \frac{1}{2}\end{array}$ & $\begin{array}{l}\text { March 27, } 1942 \\
\text { April 7, } 1942\end{array}$ & $\begin{array}{c}\frac{7 *}{6} \\
\frac{7}{23}\end{array}$ & $\begin{array}{r}\frac{6}{137} \\
\frac{9}{\infty}\end{array}$ & $\begin{array}{l}\frac{4}{92} \\
\frac{8}{\infty}\end{array}$ \\
\hline 2 & $\underset{3649}{\text { H. T. }}$ & 10 & October 27, 1941 & $+t$ & 50 to 250 & $\begin{array}{l}5 \frac{1}{2} \\
7\end{array}$ & $\begin{array}{l}\text { April 9, } 1942 \\
\text { May 28, } 1942\end{array}$ & $\begin{array}{r}\frac{4}{36} \\
\frac{2}{17}\end{array}$ & $\begin{array}{c}6 \\
\text { manyt } \\
\frac{2}{416}\end{array}$ & $\begin{array}{r}0 \\
\text { many } \\
\frac{5}{275}\end{array}$ \\
\hline 3 & D. B. & 14 & October 28, 1941 & ++ & 80 to 165 & $\begin{array}{l}5 \\
5 \frac{1}{2}\end{array}$ & $\begin{array}{l}\text { March 31, } 1942 \\
\text { April 16, } 1942\end{array}$ & $\begin{array}{l}\frac{5}{0} \\
3 \\
\overline{4}\end{array}$ & $\begin{array}{r}\frac{2}{110} \\
\frac{7}{258}\end{array}$ & $\begin{array}{r}\frac{7}{299} \\
\frac{16}{262}\end{array}$ \\
\hline 4 & J. C. & 8 & November 2, 1941 & $+t$ & 32 to 400 & $\begin{array}{l}5 \frac{1}{2} \\
6\end{array}$ & $\begin{array}{l}\text { April 16, } 1942 \\
\text { May 3, } 1942\end{array}$ & $\begin{array}{l}\frac{1}{33} \\
\frac{2}{0}\end{array}$ & $\begin{array}{r}\frac{7}{258} \\
\frac{5}{\infty}\end{array}$ & $\frac{16}{262}$ \\
\hline 5 & A.F. & 9 & November 4, 1941 & ++ & 50 to 80 & $\begin{array}{r}5 \\
6 \frac{1}{2} \\
8 \frac{1}{2} \\
14 \\
16 \\
17\end{array}$ & $\begin{array}{l}\text { April 9, } 1942 \\
\text { May 18, } 1942 \\
\text { July 14, } 1942 \\
\text { January 6, } 1943 \\
\text { March 25, } 1943 \\
\text { April 28, } 1943\end{array}$ & $\begin{array}{r}\frac{1}{8} \\
\frac{2}{8} \\
\frac{5}{17} \\
\frac{2}{1} \\
\frac{3}{92} \\
\frac{2}{141}\end{array}$ & $\begin{array}{r}\frac{6}{\text { many }} \\
\frac{1}{190} \\
\frac{10}{\infty} \\
\frac{2}{\operatorname{many}} \\
\frac{5}{\infty} \\
\frac{4}{\operatorname{many}}\end{array}$ & $\begin{array}{r}\frac{0}{\operatorname{many}} \\
\frac{1}{189} \\
\frac{5}{\infty} \\
\frac{3}{\operatorname{many}} \\
\frac{2}{\infty} \\
\frac{5}{\infty}\end{array}$ \\
\hline
\end{tabular}

* The numerator indicates the number of colonies in the plate poured before and the denominator the number in the plate poured after 3 hours' incubation.

t Many $=500$ to 1000 colonies. 
TABLE I-Continued

\begin{tabular}{|c|c|c|c|c|c|c|c|c|c|c|}
\hline \multirow{3}{*}{$\begin{array}{l}\text { Case } \\
\text { No. }\end{array}$} & \multirow{3}{*}{$\begin{array}{c}\text { Name } \\
\text { Hosp. } \\
\text { No. }\end{array}$} & \multirow{3}{*}{ Age } & & & \multirow{3}{*}{$\begin{array}{l}\text { Rise in anti- } \\
\text { streptolysin } \\
\text { O titer }\end{array}$} & \multirow{3}{*}{$\begin{array}{c}\text { Interval } \\
\text { between } \\
\text { infection } \\
\text { and } \\
\text { tests }\end{array}$} & \multirow{3}{*}{ Dates of tests } & \multicolumn{3}{|c|}{ Results } \\
\hline & & & \multicolumn{2}{|c|}{ Pharyngitis } & & & & Patient & $\begin{array}{l}\text { Childr } \\
\text { escape } \\
36 \text { pha }\end{array}$ & $\begin{array}{l}\text { n who } \\
\text { dype } \\
\text { yngitis }\end{array}$ \\
\hline & & & Date & Severity & & & & & $\begin{array}{l}\text { Control } \\
\text { No. } 1\end{array}$ & $\begin{array}{c}\text { Control } \\
\text { No. } 2\end{array}$ \\
\hline
\end{tabular}

9 PATIENTS WHO DEVELOPED RHEUMATIC MANIFEstations-Continued

\begin{tabular}{|c|c|c|c|c|c|c|c|c|c|c|}
\hline 6 & C. D. & $\begin{array}{c}\text { years } \\
11\end{array}$ & November 4, 1941 & $\begin{array}{c}0 \\
\\
\text { (Throat } \\
\text { culture } \\
\text { positive) }\end{array}$ & $\begin{array}{c}\text { units } \\
125 \text { to } 500\end{array}$ & $\begin{array}{c}\text { months } \\
5 \\
6 \\
17\end{array}$ & $\begin{array}{l}\text { April 7, } 1942 \\
\text { May 7, } 1942 \\
\text { April 28, } 1943\end{array}$ & $\begin{array}{r}\frac{5}{14} \\
\frac{5}{11} \\
\frac{3}{243}\end{array}$ & $\begin{array}{l}\frac{9}{\infty} \\
\frac{5}{\infty} \\
\frac{5}{\infty}\end{array}$ & $\frac{2}{\text { many }}$ \\
\hline 7 & H. L. & 7 & November 6, 1941 & ++ & 125 to 400 & $\begin{array}{l}5 \\
6 \frac{1}{2}\end{array}$ & $\begin{array}{l}\text { April 16, } 1942 \\
\text { May 28, } 1942\end{array}$ & $\begin{array}{l}0 \\
\overline{1} \\
\frac{2}{0}\end{array}$ & $\begin{array}{r}\frac{7}{258} \\
\frac{5}{275}\end{array}$ & $\frac{2}{416}$ \\
\hline 8 & $\underset{3596}{\text { M. M. }}$ & 11 & December 7, 1941 & + & 200 to 600 & $\begin{array}{l}3 \frac{1}{2} \\
5 \\
6\end{array}$ & $\begin{array}{l}\text { March 23, } 1942 \\
\text { May 3, } 1942 \\
\text { June 4, } 1942\end{array}$ & $\begin{array}{r}\frac{24}{13} \\
\frac{5}{0} \\
0 \\
\frac{0}{2}\end{array}$ & $\begin{array}{r}\frac{36}{\infty} \\
\frac{5}{\infty} \\
\frac{2}{166}\end{array}$ & $\frac{33}{\infty}$ \\
\hline 9 & E. J. & 12 & November 16, 1941 & \pm & 125 to 165 & $4 \frac{1}{2}$ & $\begin{array}{l}\text { March 31, } 1942 \\
\text { April 21, } 1942 \\
\text { May 14, } 1942\end{array}$ & $\begin{array}{r}\frac{3}{31} \\
\frac{6}{11} \\
\frac{1}{6}\end{array}$ & $\begin{array}{r}\frac{7}{299} \\
\frac{4}{246} \\
\frac{0}{135}\end{array}$ & $\begin{array}{r}\frac{2}{110} \\
\frac{4}{204} \\
\frac{2}{121}\end{array}$ \\
\hline
\end{tabular}

7 PATIENTS Who ESCAPED RHEUMatic SEQUelaE

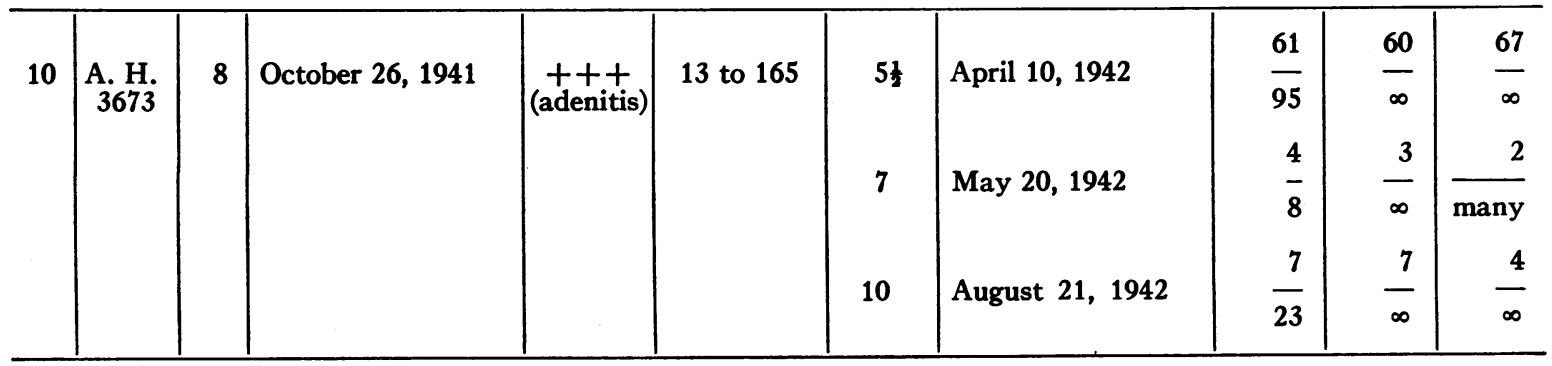




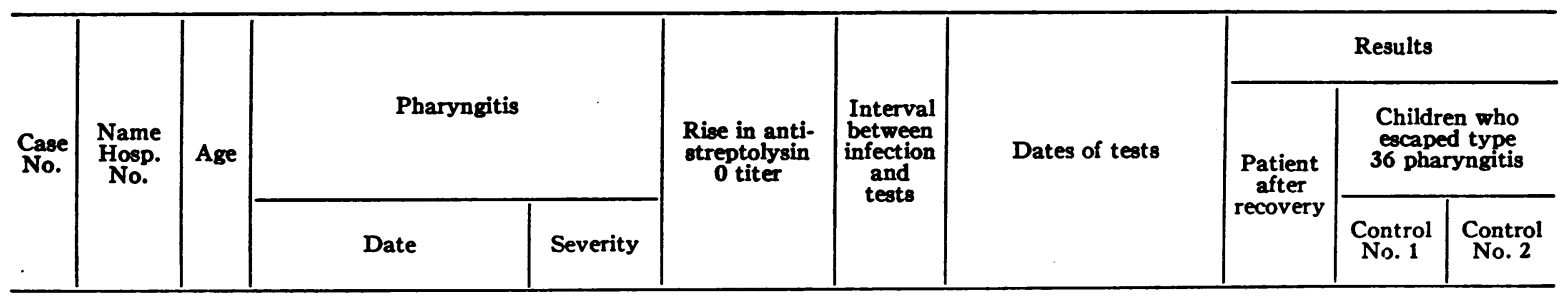

7 PATIENTS Who ESCAPEd RHEUMatic SEQUelae-Continued

\begin{tabular}{|c|c|c|c|c|c|c|c|c|c|c|}
\hline 11 & D. G. & $\begin{array}{c}\text { years } \\
7\end{array}$ & October 31, 1941 & ++ & $\begin{array}{c}\text { unils } \\
50 \text { to } 100\end{array}$ & $\begin{array}{c}\text { months } \\
5 \\
7 \\
12\end{array}$ & $\begin{array}{l}\text { March 27, } 1942 \\
\text { May 26, } 1942 \\
\text { October 30, } 1942\end{array}$ & $\begin{array}{l}4 \\
\overline{0} \\
1 \\
\overline{2} \\
5 \\
\overline{0}\end{array}$ & $\begin{array}{r}\frac{6}{137} \\
\frac{2}{127} \\
\frac{3}{\text { many }}\end{array}$ & $\begin{array}{r}\frac{4}{92} \\
\frac{2}{98} \\
\frac{1}{277}\end{array}$ \\
\hline 12 & $\mid \begin{array}{c}\text { J. O'L. } \\
\text { Of626 }\end{array}$ & 11 & November 4, 1941 & ++ & 32 to 80 & $\begin{array}{l}5 \\
7 \frac{1}{2}\end{array}$ & $\begin{array}{l}\text { April 3, } 1942 \\
\text { June 25, } 1942\end{array}$ & $\begin{array}{l}\frac{5}{4} \\
0 \\
\frac{3}{3}\end{array}$ & $\begin{array}{r}\frac{3}{107} \\
\frac{0}{\infty}\end{array}$ & $\begin{array}{r}\frac{3}{106} \\
\frac{1}{\text { many }}\end{array}$ \\
\hline 13 & $\underset{3635}{\text { M. C. }}$ & 8 & November 5, 1941 & $+t$ & 60 to 100 & $\begin{array}{r}5 \frac{1}{2} \\
7 \\
13\end{array}$ & $\begin{array}{l}\text { April 21, } 1942 \\
\text { June 12, } 1942 \\
\text { December } 15,1942\end{array}$ & $\begin{array}{l}\frac{1}{1} \\
\frac{3}{0} \\
\frac{3}{39}\end{array}$ & $\begin{array}{r}\frac{4}{246} \\
\frac{0}{\text { many }} \\
\frac{2}{\text { many }}\end{array}$ & $\begin{array}{r}\frac{4}{204} \\
\frac{1}{\text { many }} \\
6 \\
\frac{6}{\text { many }}\end{array}$ \\
\hline 14 & $\underset{3682}{\text { M. N. }}$ & 8 & November 9, 1941 & ++ & no change & $\begin{array}{l}5 \\
6 \frac{1}{2} \\
8 \frac{1}{2} \\
14 \\
16\end{array}$ & $\begin{array}{l}\text { April 7, } 1942 \\
\text { May 28, } 1942 \\
\text { August 27, } 1942 \\
\text { January 26, } 1943 \\
\text { March 25, } 1943\end{array}$ & $\begin{array}{r}\overline{7} \\
0 \\
\frac{4}{3} \\
\frac{0}{16} \\
\frac{8}{11} \\
7 \\
\text { many }\end{array}$ & $\begin{array}{r}\frac{8}{\infty} \\
\frac{1}{216} \\
\frac{0}{383} \\
\frac{6}{\operatorname{many}} \\
\frac{2}{\infty}\end{array}$ & $\begin{array}{r}\frac{9}{\infty} \\
\frac{1}{190} \\
\frac{0}{407}\end{array}$ \\
\hline 15 & $\underset{3734}{\text { K. W. }}$ & 11 & November 14, 1941 & $\begin{array}{c}0 \\
\\
\text { (Throat } \\
\text { culture } \\
\text { positive) }\end{array}$ & 100 to 165 & $5 \frac{1}{2}$ & $\begin{array}{l}\text { April 23, } 1942 \\
\text { May 28, } 1942\end{array}$ & $\begin{array}{l}\frac{0}{10} \\
\frac{2}{8}\end{array}$ & $\begin{array}{r}\frac{0}{258} \\
\frac{2}{416}\end{array}$ & $\begin{array}{r}\frac{0}{70} \\
\frac{5}{275}\end{array}$ \\
\hline 16 & C. B. & 13 & December 31, 1941 & $\begin{array}{c}0 \\
\\
\text { (Throat } \\
\text { culture } \\
\text { positive) }\end{array}$ & 60 to 100 & 4 & $\begin{array}{l}\text { April 21, } 1942 \\
\text { May 24, } 1942\end{array}$ & $\begin{array}{l}\frac{2}{23} \\
\frac{2}{6}\end{array}$ & $\begin{array}{r}\frac{4}{246} \\
0 \\
\text { many }\end{array}$ & $\begin{array}{r}\frac{4}{204} \\
0 \\
\text { many }\end{array}$ \\
\hline
\end{tabular}


one child known to have no bacteriostatic activity against type 36 streptococcus was used throughout the experiment. Five-tenths cc. of the serum to be tested was added to $0.9 \mathrm{cc}$. of this boy's blood. The results are presented in Table II.

Unfortunately, only small amounts of sera obtained before the attack of pharyngitis were available and the tests therefore could not be repeated. Although the bacteriostatic activity of the sera was weak, in 4 of the 6 cases, a definite difference between the sera taken before and after infection was apparent.

\section{Specificity of the bacteriostatic activity of the blood of patients, following recovery from strepto- coccal pharyngitis}

Strains of heterologous types (types $6,15,19$, 26 , and 39), isolated from patients with acute pharyngitis, were included in many of the tests. It was shown by Todd (17) that the virulence of streptococci can be judged by their ability to grow in the blood of normal individuals. Although the heterologous types were recently isolated, most of these strains appeared to be of low virulence and failed to grow in human blood unless a fairly large number of bacteria were inoculated. With the homologous strain, type 36 , a considerable variation in the size of the inoculum did not alter the results. With the heterologous types, the bacteriostatic activity of the blood of many of the children varied with the number of bacteria inoculated. In many instances, when a small inoculum was used, the blood appeared to be bacteriostatic, whereas, with a larger inoculum, the bacteria were able to multiply. Furthermore, the findings with heterologous types were of ten equivocal because no definite contrast between the child who had recovered from the type 36 streptococcal pharyngitis and the children chosen to serve as controls was obtained. In most instances, however, the bacteriostatic effect was more marked against the homologous type 36 than against heterologous types.

Absorption. It was thought of interest to determine whether the bacteriostatic activity of sera obtained from children whose whole blood inhibited the growth of type 36 streptococcus could be reduced by absorption with the homologous strain. The inactivated serum in each in- stance was divided into 3 parts: one part was not absorbed, one was absorbed with the homologous strain, and one with a streptococcus of a heterologous type. Two parts of serum were mixed with one part of heat-killed bacterial sediment, and incubated at $37^{\circ} \mathrm{C}$. for 30 minutes. The mixture was allowed to stand overnight in the ice box, centrifuged the following morning, and the clear serum pipetted off. Five-tenths cc. of each of these sera was added to $0.9 \mathrm{cc}$. of whole heparinized blood, obtained from a child known to have no bacteriostatic action against type 36 streptococcus.

The indirect method of doing bacteriostatic tests, using serum and blood from a control, usually gave less definite results than those obtained with whole blood of children following recovery from type 36 pharyngitis. In most instances, however, the bacteriostatic action of serum absorbed with the homologous type was reduced, as compared with the unabsorbed serum or that absorbed with a heterologous type. A protocol illustrating these findings is presented in Table III. The bacteriostatic effect as shown in this table is most marked with serum obtained from Case 5 although this child was bled 16 months after the attack of pharyngitis. In all 3 of these cases, the bacteriostatic action of the serum was definitely reduced after absorption with the homologous type.

\section{Comparison of the bacteriostatic activity of the blood of children receiving prophylactic doses of sulfanilamide with that of children after recovery from pharyngitis}

In a number of experiments, the blood of patients receiving daily prophylactic doses of sulfanilamide was included. No para-aminobenzoic acid was added. It was found that, in most instances, the blood of patients containing concentrations of free sulfanilamide, varying from 1.2 to 2 mgm. per cent, was less bacteriostatic for type 36 streptococcus than that of children who had recovered from pharyngitis due to this microorganism.

\section{Is type 36 streptococcus peculiarly susceptible to the bactericidal action of serum described by Tillett?}

It was noted by Tillett that different strains of streptococci varied greatly in their suscepti- 
TABLE II

Comparison of the bacteriostatic activity of serum obtained before and after infection with type 36 streptococcus

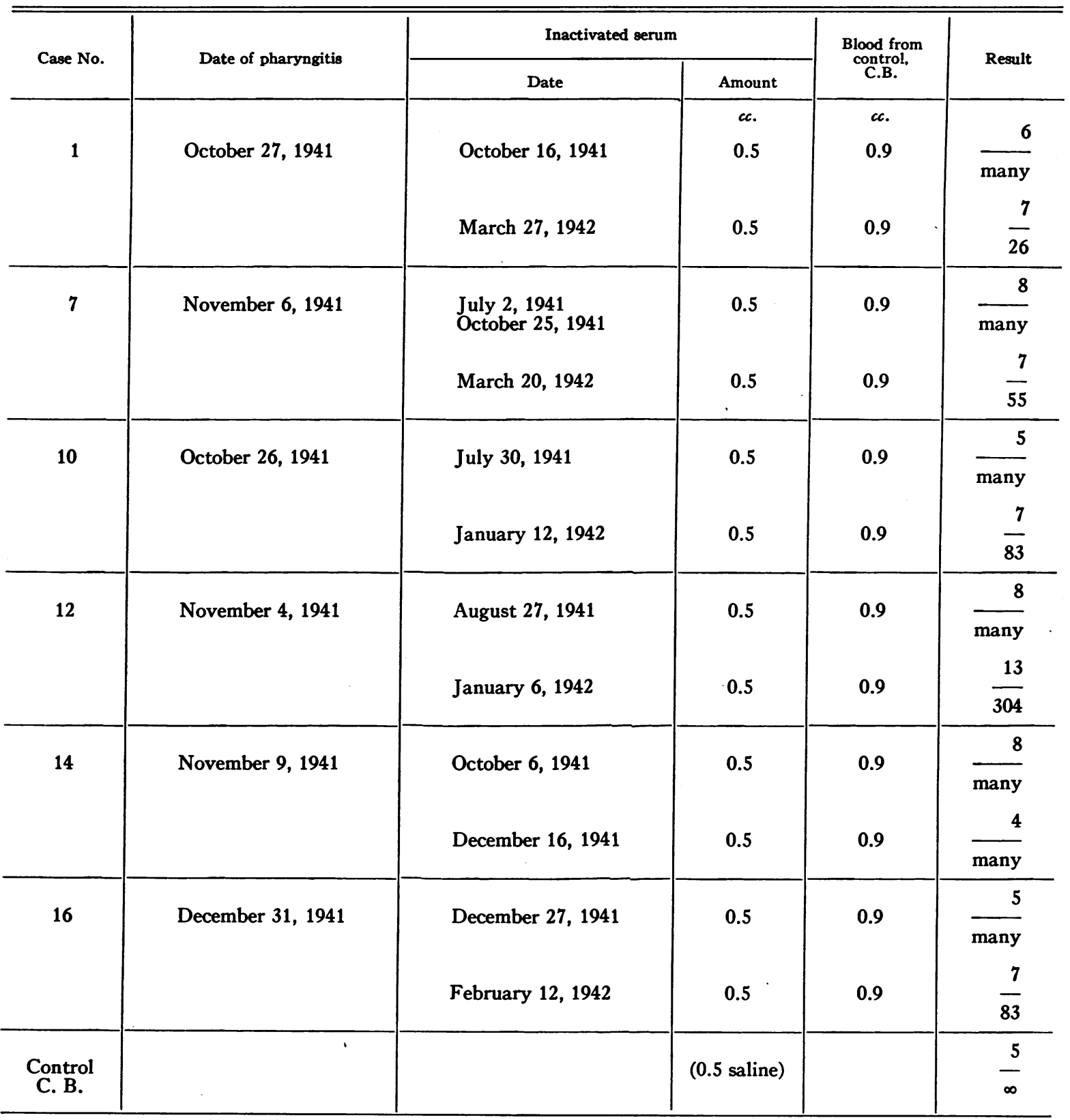

bility to the non-specific bactericidal action of sera obtained from febrile patients (5). Although all the children whose blood was used in the bacteriostatic tests were afebrile and had no complaints or symptoms, in a few experiments, the bacteriostatic action of fresh serum was compared with that of whole blood obtained from the same individual. In spite of the fact that the blood was definitely bacteriostatic, it was found that type 36 streptococcus multiplied freely in the serum. The bactericidal action of fresh serum obtained from one patient with active rheumatic fever, whose temperature ranged between 101.8 to $103^{\circ} \mathrm{F}$. on the day of the test, was also tried with type 36 streptococcus. No bactericidal effect was noted. Thus, no evidence 
TABLE III

Effect of absorption with the homologous type and a heterologous type of sera, obtained from children after recovery from streptococcus type 36 pharyngitis

\begin{tabular}{|c|c|c|c|c|c|c|}
\hline \multirow{2}{*}{$\begin{array}{l}\text { Case } \\
\text { No. }\end{array}$} & \multirow{2}{*}{ Date of pharyngitis } & \multirow{2}{*}{ Date serum obtained } & \multicolumn{2}{|l|}{ Inactivated serum } & \multirow{2}{*}{$\begin{array}{c}\text { Whole } \\
\text { blood from } \\
\text { control } \\
\text { J.M. }\end{array}$} & \multirow{2}{*}{ Result } \\
\hline & & & Absorption & Amount & & \\
\hline 5 & November 4, 1941 & March 25, 1943 & $\begin{array}{l}\text { Unabsorbed } \\
\text { Absorbed with homologous type } 36 \\
\text { Absorbed with heterologous type } 11\end{array}$ & $\begin{array}{l}c c . \\
0.5 \\
0.5 \\
0.5\end{array}$ & $\begin{array}{l}c c . \\
0.9 \\
0.9 \\
0.5\end{array}$ & $\begin{array}{r}\frac{3}{57} \\
\frac{3}{\operatorname{many}} \\
\frac{3}{59}\end{array}$ \\
\hline 6 & November 4, 1941 & $\begin{array}{l}\text { Pooled sera ob- } \\
\text { tained between De- } \\
\text { cember } 9,1941 \text { and } \\
\text { July } 2,1942\end{array}$ & $\begin{array}{l}\text { Unabsorbed } \\
\text { Absorbed with homologous type } 36 \\
\text { Absorbed with heterologous type } 11\end{array}$ & $\begin{array}{l}0.5 \\
0.5 \\
0.5\end{array}$ & $\begin{array}{l}0.9 \\
0.9 \\
0.9\end{array}$ & $\begin{array}{r}\frac{4}{89} \\
0 \\
\frac{1}{\operatorname{many}} \\
\cdot \frac{1}{117}\end{array}$ \\
\hline 11 & October 31, 1941 & March 30, 1943 & $\begin{array}{l}\text { Unabsorbed } \\
\text { Absorbed with homologous type } 36 \\
\text { Absorbed with heterologous type } 11\end{array}$ & $\begin{array}{l}0.5 \\
0.5 \\
0.5\end{array}$ & $\begin{array}{l}0.9 \\
0.9 \\
0.9\end{array}$ & $\begin{array}{r}\frac{3}{341} \\
\frac{3}{\text { many }} \\
\frac{2}{146}\end{array}$ \\
\hline & & $\begin{array}{l}\text { Serum from control } \\
\text { S. A. }\end{array}$ & Unabsorbed & 0.5 & 0.9 & $\frac{3}{\operatorname{many}}$ \\
\hline & & $\begin{array}{l}\text { Serum from control } \\
\text { M. } \mathrm{H} \text {. }\end{array}$ & Unabsorbed & 0.5 & 0.9 & $\frac{0}{\operatorname{many}}$ \\
\hline & & & & & 1.4 & $\frac{3}{\operatorname{many}}$ \\
\hline
\end{tabular}

was obtained to suggest that the phenomenon described by Tillett played a part in our findings.

\section{Is the bacteriostatic action of the blood demonstrable} in children following recovery from upper respiratory infections due to other types of Group $A$ streptococcit

Type 15 streptococcus. Blood was obtained from 5 children, who had had pharyngitis, due to type 15 streptococcus, 15 to 18 months after the upper respiratory infection. No definite bacteriostatic effect against the homologous type was demonstrable.

Type 19 streptococcus. The blood of 2 children, who had had upper respiratory infections associated with type 19 streptococcus during the winter of 1942, was tested with the homologous type and with 2 heterologous types. In one of these patients, the bacteriostatic action of the blood for type 19 streptococcus had been determined be- 
fore the infection occurred, and in the other, the first test was done 3 weeks after the attack of pharyngitis. Further tests were performed with the blood of both children, at frequent intervals for periods of 5 to 6 months. In some instances, the blood was set up in duplicate and inoculated with varying numbers of bacteria. In one experiment, the bacteriostatic activity of whole blood was compared with that of freshly obtained serum.
The data presented in Table IV indicate that the bacteriostatic action of the blood in the case of these 2 children became demonstrable only 2 to 3 months after infection. At this time, the serum, in contrast to the whole blood, showed no bactericidal or bacteriostatic effect. The blood of neither of these 2 individuals inhibited the growth of 2 heterologous types, 36 and 37 . The bacteriostatic action of $\mathrm{J}$. C.'s blood for the homologous type 19 streptococcus was slightly

TABLE IV

Bacteriostatic tests using the homologous and heterologous types with blood and serum obtained from 2 children who had type 19 streptococcal pharyngitis

\begin{tabular}{|c|c|c|c|c|c|c|c|c|c|c|c|}
\hline \multirow{4}{*}{ Name } & \multirow{3}{*}{\multicolumn{2}{|c|}{ Pharyngitis }} & \multirow{4}{*}{$\begin{array}{l}\text { Rise in } \\
\text { antistrep- } \\
\text { tolysin } 0 \\
\text { titer }\end{array}$} & \multirow{4}{*}{$\begin{array}{l}\text { Interval } \\
\text { between } \\
\text { infection } \\
\text { and tests }\end{array}$} & \multirow{4}{*}{$\begin{array}{c}\text { Dates of } \\
\text { tests }\end{array}$} & \multirow{4}{*}{$\begin{array}{l}\text { Strains of } \\
\text { streptococci }\end{array}$} & \multicolumn{5}{|c|}{ Results } \\
\hline & & & & & & & \multirow{2}{*}{\multicolumn{2}{|c|}{ Patient }} & \multicolumn{3}{|c|}{$\begin{array}{l}\text { Children who escaped } \\
\text { type } 19 \text { pharyngitis }\end{array}$} \\
\hline & & & & & & & & & \multicolumn{2}{|c|}{$\underset{1}{\text { Control }}$} & \multirow{2}{*}{$\begin{array}{c}\begin{array}{l}\text { Con- } \\
\text { trol } 2\end{array} \\
\begin{array}{l}\text { Whole } \\
\text { blood }\end{array}\end{array}$} \\
\hline & Date & $\begin{array}{c}\text { Sever- } \\
\text { ity }\end{array}$ & & & & & $\begin{array}{l}\text { Whole } \\
\text { blood }\end{array}$ & $\begin{array}{l}\text { Fresh } \\
\text { serum }\end{array}$ & $\begin{array}{l}\text { Whole } \\
\text { blood }\end{array}$ & $\begin{array}{l}\text { Fresh } \\
\text { serum }\end{array}$ & \\
\hline \multirow[t]{5}{*}{ J. C. } & \multirow[t]{5}{*}{ October 26, 1942} & \multirow[t]{5}{*}{+++} & \multirow[t]{5}{*}{ No change } & 3 weeks & November 18, 1942 & Homol.* type 19 & $\begin{array}{r}0.9 c c . \\
\frac{2}{\operatorname{many}}\end{array}$ & $0.9 \mathrm{cc}$. & $\begin{array}{r}0.9 \mathrm{cc} . \\
\frac{1}{\text { many }}\end{array}$ & $0.9 \mathrm{cc}$. & $\begin{array}{r}0.9 c c . \\
\frac{3}{267}\end{array}$ \\
\hline & & & & 5 weeks & December 4, 1942 & Homol. type 19 & $\frac{0}{\operatorname{many}}$ & & $\frac{0}{\operatorname{many}}$ & & $\frac{1}{327}$ \\
\hline & & & & 3 months & January 29, 1943 & Homol. type 19 & $\frac{3}{1}$ & $\frac{3}{\operatorname{man} y}$ & $\frac{1}{\operatorname{man} y}$ & $\frac{3}{\operatorname{man} y}$ & \\
\hline & & & & $3 \frac{1}{2}$ months & February 19, 1943 & $\begin{array}{l}\text { Homol. type } 19 \\
\text { Heter.** type } 37\end{array}$ & $\begin{array}{r}\frac{4}{27} \\
\frac{1}{208}\end{array}$ & & $\begin{array}{l}\frac{3}{\text { many }} \\
\frac{0}{\text { many }}\end{array}$ & & $\begin{array}{r}\frac{6}{\infty} \\
\frac{3}{\operatorname{many}}\end{array}$ \\
\hline & & & & 6 months & April 28, 1943 & $\begin{array}{l}\text { Homol. type } 19 \\
\text { Heter. type } 36\end{array}$ & $\begin{array}{r}\frac{1}{7} \\
0 \\
\operatorname{many}\end{array}$ & & $\begin{array}{r}\frac{1}{\operatorname{many}} \\
\frac{5}{480}\end{array}$ & & $\begin{array}{r}\frac{3}{\infty} \\
\frac{2}{\operatorname{many}}\end{array}$ \\
\hline \multirow[t]{4}{*}{ H. R. } & \multirow{4}{*}{ December 1, 1942} & \multirow{4}{*}{++} & \multirow{4}{*}{ No change } & \begin{tabular}{|l} 
Before \\
infection
\end{tabular} & November 14, 1942 & Homol. type 19 & $\frac{1}{\operatorname{many}}$ & & $\frac{0}{113}$ & & $\frac{0}{66}$ \\
\hline & & & & 2 months & January 29, 1943 & Homol. type 19 & $\frac{3}{50}$ & $\frac{2}{\operatorname{many}}$ & $\frac{1}{\operatorname{man} y}$ & $\frac{3}{\operatorname{many}}$ & \\
\hline & & & & 21 months & February 19, 1943 & $\begin{array}{l}\text { Homol. type } 19 \\
\text { Heter. type } 37\end{array}$ & $\begin{array}{r}\frac{0}{46} \\
\frac{5}{\infty}\end{array}$ & & $\begin{array}{r}\frac{3}{\operatorname{many}} \\
\frac{0}{\operatorname{many}}\end{array}$ & & $\begin{array}{r}\frac{6}{\infty} \\
\frac{3}{\text { many }}\end{array}$ \\
\hline & & & & 5 months & April 28, 1943 & $\begin{array}{l}\text { Homol. type } 19 \\
\text { Heter. type } 36\end{array}$ & $\begin{array}{r}\frac{1}{58} \\
1 \\
\text { many }\end{array}$ & & $\begin{array}{r}\frac{1}{\operatorname{many}} \\
\frac{5}{480}\end{array}$ & & $\begin{array}{r}\frac{1}{\infty} \\
\frac{2}{\operatorname{many}}\end{array}$ \\
\hline
\end{tabular}

* Homol. = Homologous.

** Heter. = Heterologous. 
more marked than that of $H$. R. The clinical symptoms were also somewhat more severe in the former patient.

\section{Limitations of bacteriostatic tests}

Different observers have used various methods of doing bactericidal tests. Most investigators have emphasized the difficulties and numerous sources of error inherent in this technique.

The modification of the method employed by us differs from that used by other observers in that we obtained merely a bacteriostatic and not a bactericidal effect. The number of bacteria inoculated was small and the period of incubation short. It is only by comparing the results obtained with the blood of suitable controls that our findings are of interest.

\section{DISCUSSION}

The development of bacteriostatic properties in the blood of patients following recovery from streptococcal pharyngitis due to a single type of Group A hemolytic streptococcus, type 36 , is reported. This property persisted for many months and in some instances was still demonstrable a year after the upper respiratory infection. It developed irrespective of whether the symptoms caused by the pharyngitis were mild or severe and occurred both in patients who escaped and those who developed rheumatic sequelae.

At the present time, the majority of investigators agree that rheumatic recurrences usually follow in the wake of streptococcal pharyngitis. One of the major concerns of physicians who have rheumatic patients under their care is the prevention of this kind of upper respiratory infection. It has been shown by several observers that streptococcal pharyngitis and rheumatic relapses can be prevented by the prophylactic administration of sulfanilamide (18 to $20,4,10)$. There are, however, many objections to prolonged sulfonamide prophylaxis and it seems worthwhile therefore to investigate the possibility that type specific immunity may develop.

It is noteworthy that in outbreaks of streptococcal pharyngitis or scarlet fever due to a single type of Group A hemolytic streptococci, a large proportion of the individuals exposed escape in- fection. At the present time, the nature of this resistance is not understood. It may indicate a previous infection with the same type or with types so closely related antigenically than an overlapping immunity is produced. If typespecific immunity does develop, it may be cellular and bear no relation to humoral antibodies. On the other hand, it is entirely possible that the failure to contract infection depends on unknown non-specific factors.

During the course of the outbreak of pharyngitis, due to type 36 streptococcus, the failure of certain children to contract this infection, in spite of exposure, was striking. It was thought that if the resistance of these individuals was due to a previous infection with this type of streptococcus, bacteriostatic properties might still be demonstrable in their blood. The results of these tests, however, were entirely negative. It may be that, after a lapse of time, bacteriostatic activity is no longer demonstrable in the blood and that these humoral antibodies represent a temporary expression of a more permanent cellular immunity.

Bacteriostatic tests failed to elucidate the nature of the resistance to streptococcal pharyngitis of individuals who escaped infection. The fact that this property was demonstrable in the blood of patients recovering from pharyngitis due to Group A of a single type, however, gives us another method for studying the development of type-specific immunity following streptococcal upper respiratory infections. By means of this technique, it may be possible to answer the much disputed question: Are so-called "contact" carriers, who during outbreaks of streptococcal pharyngitis acquire the epidemic-inducing strain, really cases of subclinical infection?

\section{SUMMARY}

The development of bacteriostatic properties in the blood of children, after recovery from upper respiratory infections due to Group A streptococci of a single type, is reported.

\section{BIBLIOGRAPHY}

1. Fothergill, L. D., and Lium, R., Value of commercial antibacterial streptococcus sera in hemolytic streptococcus infections. New England J. Med., 1934, 211, 99. 
2. Hare, R., Alterations in the bactericidal power of the blood which occur during haemolytic streptococcal infections in the puerperium. J. Path. and Bact., 1935, 41, 61.

3. Spink, W. W., and Keefer, C. S., Studies of hemolytic streptococcal infection. II. The serological reactions of the blood during erysipelas. J. Clin. Invest., 1936, 15, 21.

4. Chandler, C. A., and Taussig, H. B., Sulfanilamide as a prophylactic agent in rheumatic fever. Bull. Johns Hopkins Hosp., 1943, 72, 42.

5. Tillett, W. S., The bactericidal action of human serum on hemolytic streptococci. I. Observations made with serum from patients with acute infections and from normal individuals. J. Exper. Med., 1937, $65,147$.

6. Swift, H. F., and Hodge, B. E., Type-specific anti-M precipitins in rheumatic and non-rheumatic patients with hemolytic streptococcal infections. Proc. Soc. Exper. Biol. and Med., 1936, 34, 849.

7. Walker, D. W., Application of the technique of slide agglutination of hemolytic streptococci to human sera. Proc. Soc. Exper. Biol. and Med., 1941, 48, 338.

8. Rantz, L. A., Kirby, W. M. M., and Jacobs, A. H., Group A hemolytic streptococcus antibodies. I. Griffith type agglutinin and antistreptolysin titers in normal men and in acute infections. J. Clin. Invest., 1943, 22, 411.

9. Diefendorf, H. W., A method for detecting in human serum protective bodies against hemolytic streptococci. Proc. Soc. Exper. Biol. and Med., 1941, 48, 56.

10. Kuttner, A. G., and Reyersbach, G., The prevention of streptococcal upper respiratory infections and rheumatic recurrences in rheumatic children by the prophylactic use of sulfanilamide. J. Clin. Invest., 1943, 22, 77.

11. Krumwiede, E., A comparison of the value of the agglutination and precipitin reactions in the serological typing of Group A streptococci. J. Bact., 1943, 46, 117.

12. Griffith, F., The serological classification of streptococcus pyogenes. J. Hyg., 1934, 34, 542.

13. Lancefield, R. C., Antigenic complex of streptococcus haemolyticus; demonstration of type-specific substance in extracts of streptococcus haemolyticus. J. Exper. Med., 1928, 47, 91.

14. Kuttner, A. G., and Krumwiede, E., Observations on the effect of streptococcal upper respiratory infections on rheumatic children: A three year study. J. Clin. Invest., 1941, 20, 273.

15. Todd, E. W., A method of measuring the increase or decrease of the population of haemolytic streptococci in blood. Brit. J. Exper. Path., 1927, 8, 1.

16. Brown, J. H., Vacuum tubes for the storage and. shipment of bacteria. Science, 1926, 64, 429.

17. Todd, E. W., Observations on the virulence of haemolytic streptococci. Brit. J. Exper. Path., 1927, 8, 289.

18. Thomas, C. B., France, R., and Reichsman, F., The prophylactic use of sulfanilamide in patients susceptible to rheumatic fever. J. A. M. A., 1941, 116, 551.

19. Coburn, A. F., and Moore, L. V., The prophylactic use of sulfanilamide in streptococcal respiratory infections, with special reference to rheumatic fever. J. Clin. Invest., 1939, 18, 147.

20. Hansen, A. E., Platou, R. V., and Dwan, P. F., Prolonged use of a sulfonamide compound in prevention of rheumatic recrudescences in children: An evaluation based on a four year study on sixty-foni children. Am. J. Dis. Child., 1942, 64, 963. 